Sri Lanka J. Aquat. Sci. 21 (2) (2016): 105-112

\title{
Toxicity of aqueous extract of white hoary pea, Tephrosia candida (Papilionoideae) on Nile tilapia, Oreochromis niloticus (Cichlidae) fingerlings
}

\author{
C.R.W.C. MOHOTTI and U.P.K. EPA* \\ Department of Zoology and Environmental Management, University of Kelaniya, \\ Kelaniya 11600, Sri Lanka \\ * Corresponding author (epa@kln.ac.lk)
}

\begin{abstract}
Fish poisoning using Tephrosia candida, which is an exotic plant to Sri Lanka is taking place in streams in the boundary of the Sinharaja forest, a tropical forest range, designated as a world heritage site by UNESCO in 1988. T. candida is a source of flavonoids and rotenoids including rotenone, tephrosin, and deguelin. Fishermen add large amounts of grounded plant matter to kill almost all the fishes in the stream within a short period of time. This method of unregulated fishing may have a long term negative effect on fish diversity and abundance in the area. A $96 \mathrm{~h}$ static renewal toxicity bioassay was carried out in the laboratory to determine the median lethal concentration $\left(\mathrm{LC}_{50}\right)$ of aqueous extract of T. candida leaves on Oreochromis niloticus fingerlings. Experimental fish were exposed to test water in $20 \mathrm{~L}$ glass aquaria with concentrations of plant extract of 5, 7.5, 10, 15 and $20 \mathrm{mg} \mathrm{L}^{-1}$. All five treatments aquaria and the control aquaria without plant extract were triplicated. Fish exposed to plant extract showed symptoms of toxicity including, initial inactivation, agitated swimming, turning movement, air gulping, increased opercular movement followed by erratic swimming, loss of reflex, slow opercular movement, setting at the bottom motionless and knockdown before death. The gills of the dead fishes were damaged, swollen and external bleeding were observed. Lower concentrations of the extracts had sub lethal effects which manifested as zigzag movement, air gulping, increased opercular movement and some fish gathered near the air stones. The $\mathrm{LC}_{50}$ values at various exposure periods were $10.83 \mathrm{mg} \mathrm{L}^{-1}$ for $24 \mathrm{~h} ; 8.61 \mathrm{mg} \mathrm{L}^{-1}$ for $48 \mathrm{~h} ; 7.26 \mathrm{mg} \mathrm{L}^{-1}$ for $72 \mathrm{~h}$ and $6.43 \mathrm{mg} \mathrm{L}^{-1}$ for $96 \mathrm{~h}$. It could be concluded that the application of T. candida extract causes lethal toxic effects on fish even at very low concentrations.
\end{abstract}

Keywords: Tephrosia candida; Oreochromis niloticus; toxicity; $\mathrm{LC}_{50}$

\section{Introduction}

Many fish poisons derived from plants from different families have been used to catch fish all over the world. These poisons, also called icthyotoxins or piscicides, occur in several related plant species such as Adenia cissampeloides, Balanites aegyptiaca, Blighia sapida, 
Derris elliptica, D. trifoliata, Kigelia Africana, Mimusops elengi, Mundulea sericea, Tetrapleura tetraptera, T. candida, T. purpurea, T. virginiana and T. vogelii (Guerrero and Guerrero 1989; Neuwinger 1994; Onusiriuka and Ufodike 1994; Andrei et al. 2002; Cheenpracha et al. 2007; Negi and Kanwal 2009). The active ingredients of these plants are released by mashing and grinding the appropriate plant or plant parts, which are then introduced to the aquatic environment. Fishing using white hoary pea, T. candida (Papilionoideae, Fabaceae) takes place in the freshwater streams at the boundary of Sinharaja forest. Sinharaja forest is designated as a natural world heritage site and a man and biosphere reserve by UNESCO in 1998.

T. candida, which is toxic only to cold-blooded animals (Van Andel 2000) is an erect herb, upto $3.5 \mathrm{~m}$ tall, with straggling branches from the base. It is native to the tropical foothills of the Himalayas in India and is now cultivated and naturalized throughout Southeast Asia. It is an exotic plant to Sri Lanka, China, Indonesia, Jamaica, Japan, Malaysia, Myanmar, New Zealand and Thailand (Orwa et al. 2009). T. candida was introduced to Sri Lanka as legume live mulch for weed control and to protect soil surface (Wijewardena 1984).

The genus Tephrosia is well-known to be a rich source of flavonoids, rotenoids, terpenoids, and sterols among their secondary metabolites (Andrei et al. 2002). Some of the ingredients isolated from $T$. candida are amorphispironone, tephrospirolactone, tephrospiroketone, deguelin, candidol (Dutt and Chibber 1983), tephrosin, amorpholone (Kole et al. 1992), candidone, rotenone and scillascillin (Stephen et al. 2003).

Lethal and sub lethal concentrations of plant poisons are known to have toxic effects on fish behaviour, heamatology, histopathology, growth, reproduction, feeding, respiration and general other physiological processes of exposed organisms. Therefore, frequent addition of large amounts of plant poisons to the streams at the boundary of Sinharaja forest raises a serious issue with regard to the conservation of aquatic biodiversity. The situation is further aggravated if the practice is extended into the Sinharaja forest and into the other areas of the country.

Short-term acute toxicity test is one of the most commonly used tests in the initial evaluation of toxicity of chemicals to organisms (Murty 1986). The acute toxicity levels of aqueous extract of $T$. candida on fish has not been investigated before. In the present study, the median lethal concentrations $\left(\mathrm{LC}_{50}\right)$ of the aqueous extract of $T$. candida was evaluated on Oreochromis niloticus fingerlings with a view to providing necessary information for law enforcement authorities and policy makers. O. niloticus was used as the test organism as they are widely used in toxicity studies worldwide, could easily find from the wild environment and keep under captivity.

\section{Materials and Methods}

\section{Preparation of plant extract}

Fresh leaves of $T$. candida from the apex of the plant were collected and $75 \mathrm{~g}$ of the plant leaves were weighed and crushed with electrically powered blender for 15 min with 500 $\mathrm{ml}$ of distilled water. The aqueous suspension was filtered through a muslin cloth, centrifuged and filtrate was stored in a refrigerator for bioassay test almost immediately after extraction. 


\section{Range finding test}

Healthy $O$. niloticus fingerlings with weight of $6.9 \pm 1.5 \mathrm{~g}$ and length of $5.1 \pm 2.0 \mathrm{~cm}$ were collected from the fish breeding centre of National Aquaculture Development Authority Udawalawe, Sri Lanka. They were acclimated for two weeks in a large fiberglass tank filled with aged tap water under the laboratory conditions. During the acclimation period, the fishes were fed twice daily at $5 \%$ of the body weight with a commercial fish feed and tank water was continuously aerated. Excess feed and feces were siphoned out twice a day. A prior range finding test was conducted with $0.1-25 \mathrm{mg} \mathrm{L}^{-1}$ of $T$. candida aqueous extract to find out the exact range of concentration of plant extract to be used for the static renewal acute toxicity test (EIFAC 1983). According to the results of range finding test the concentration of $T$. candida aqueous extract used in definitive toxicity test was between 5 $-20 \mathrm{mg} \mathrm{L}^{-1}$.

\section{Definitive test}

Static renewal 96 h toxicity bioassay was carried out in glass aquaria filled with $20 \mathrm{~L}$ of aged tap water. The stock solution of aqueous extract of $T$. candida was added in required volume in order to get a concentrations of $5,7.5,10,15$ and $20 \mathrm{mg} \mathrm{L}^{-1}$ in the treatment aquaria. All the treatment aquaria and the control aquaria without plant extract were triplicated. The water was pre-aerated for $15 \mathrm{~min}$ to full oxygen saturation before the different volumes of the plant extract were added. A complete randomized design was performed in the experiment with ten fingerlings of $O$. niloticus per $20 \mathrm{~L}$ of aged water. Aquaria were well aerated and fish were not fed during the test period. Exposure media were renewed daily for four days.

The behavioural and morphological changes of fish were observed after introduction of fishes to the experimental aquaria. Mortalities of fish were observed and recorded at 24, 48, 72 and $96 \mathrm{~h}$ from stocking. A fish was considered dead when it stopped opercular movements and failed to respond to mechanical stimulation with a glass rod. At the end of the each time period, dead fingerlings in the tanks were counted and carcasses were discarded. The concentrations at which $50 \%$ mortality of fish occurred after 24,48 , 72 and $96 \mathrm{~h}$ were taken as the median lethal concentration $\left(\mathrm{LC}_{50}\right)$ for the respective times.

Temperature, $\mathrm{pH}$, total dissolved solids, conductivity and dissolved oxygen (DO) in water in all the aquaria were monitored using multi parameter water quality checker (YSI incorporated $556 \mathrm{MPS}$ ) before and after the addition of toxicant, 24, 72 and $96 \mathrm{~h}$ of fish stocking thereafter. The median lethal concentration $\left(\mathrm{LC}_{50}\right)$ values and its corresponding 95\% confidence limits were calculated by probit analysis (Agresti 1990). Physico-chemical parameters of water in treatment and control aquaria were compared by one-way ANOVA at significant level of 0.05. All the statistical tests were carried out by MINITAB software (version 14). 


\section{Results}

The $\mathrm{pH}$, temperature, total dissolved solids, dissolved oxygen and conductivity were not significantly different between the control and treatment aquaria $(\mathrm{p}>0.05$, one way ANOVA) (Table 1) during the experimental period. After exposure to aqueous extract of $T$. candida, $O$. niloticus fingerlings started to show the symptoms of toxicity including, initial inactivation, agitated swimming, turning movement, air gulping, increased opercular beat and then erratic swimming, loss of reflex followed by slow opercular movement and setting at the bottom motionless. They exhibited body imbalance and surface floating specially at higher concentrations and knockdown before death. The gills of the dead fishes were damaged, swollen and external bleedings were observed. Lower concentrations of the extracts had sub lethal effects on the fish which manifested as zigzag movement, air gulping, increased opercular movement and some fish gathered near the air stones. None of these toxic effects were observed in the fish stocked in the control tanks. The 24, 48, 72 and $96 \mathrm{~h} \mathrm{LC}_{50}$ values of aqueous extract of $T$. candida on $O$. niloticus fingerlings at $95 \%$ confidence level were 10.8, 8.6, 7.3 and 6.4 $\mathrm{mg} \mathrm{L}^{-1}$ respectively (Table 2).

The mortality of $O$. niloticus fingerlings increased with the increase in concentration of plant extract according to the mortality concentration curves obtained from probit analysis for 24, 48, 72 and $96 \mathrm{~h}$ exposure of different concentrations (Figure 1). Furthermore, $\mathrm{LC}_{50}$ values decreased with exposure time and $95 \%$ confidence limits for $\mathrm{LC}_{50}$ values overlapped between $48 \mathrm{~h}$ and $72 \mathrm{~h}$ and between $72 \mathrm{~h}$ and $96 \mathrm{~h} \mathrm{LC} \mathrm{L}_{50}$ values.

Table 1. Mean $\pm \mathrm{SD}$ (range in parenthesis) of physico-chemical parameters of water in the aquaria treated with aqueous extract of $T$. candida and the control.

\begin{tabular}{lcccccc}
\hline Parameter & \multicolumn{5}{c}{ Plant extract } \\
\cline { 2 - 7 } & Control & $5 \mathrm{mg} \mathrm{L}^{-1}$ & $7.5 \mathrm{mg} \mathrm{L}^{-1}$ & $10 \mathrm{mg} \mathrm{L}^{-1}$ & $15 \mathrm{mg} \mathrm{L}^{-1}$ & $20 \mathrm{mg} \mathrm{L}^{-1}$ \\
\hline $\mathrm{pH}$ & $7.84 \pm 0.15$ & $7.88 \pm 0.09$ & $7.89 \pm 0.10$ & $7.98 \pm 0.04$ & $8.02 \pm 0.01$ & $8.02 \pm 0.01$ \\
& $(7.4-8.0)$ & $(7.6-8.0)$ & $(7.6-8.1)$ & $(7.9-8.1)$ & $(8.0-8.1)$ & $(8.0-8.1$ \\
Temperature & $27.2 \pm 0.2$ & $27.2 \pm 0.2$ & $27.2 \pm 0.1$ & $27.3 \pm 0.1$ & $27.4 \pm 0.1$ & $27.4 \pm 0.1$ \\
${ }^{\circ} \mathrm{C}$ & $(26.9-27.6)$ & $(27.0-27.7)$ & $(27.0-27.5)$ & $(27.1-27.6)$ & $(27.2-27.7)$ & $(27.2-27.7)$ \\
Dissolved & $5.40 \pm 0.12$ & $5.35 \pm 0.75$ & $5.44 \pm 0.09$ & $5.54 \pm 0.12$ & $5.56 \pm 0.10$ & $5.51 \pm 0.08$ \\
Oxygen & $(5.10-5.61)$ & $(5.20-5.55)$ & $(5.20-5.60)$ & $(5.18-5.70)$ & $(5.30-5.80)$ & $(5.30-5.70)$ \\
$\left(\mathrm{mg} \mathrm{L}^{-1}\right)$ & & & & & & \\
Conductivity & $95 \pm 0.5$ & $95 \pm 0.5$ & $95 \pm 0.5$ & $95 \pm 0.5$ & $95 \pm 0.5$ & $95 \pm 0.3$ \\
$\left(\mu \mathrm{Cm}^{-1}\right)$ & $(94-96)$ & $(94-96)$ & $(94-96)$ & $(94-96)$ & $(94-96)$ & $(94-95)$ \\
TDS & $0.059 \pm 0.0$ & $0.058 \pm 0.0$ & $0.058 \pm 0.0$ & $0.059 \pm 0.0$ & $0.059 \pm 0.0$ & $0.059 \pm 0.0$ \\
$\left(\mathrm{mg} \mathrm{L}^{-1}\right)$ & $(0.059-0.0)$ & $(0.058-0.06)$ & $(0.058-0.06)$ & $(0.059-0.01)$ & $(0.059-0.01)$ & $(0.059-0.01$ \\
\hline
\end{tabular}

Values in rows are not significantly different $(p<0.05)$ as indicated by one way ANOVA.

Table 2. Median lethal concentrations $\left(\mathrm{LC}_{50}\right)$ of aqueous extract of $T$. candida for 24,48 , 72 and 96 h exposure of $O$. niloticus.

\begin{tabular}{ccccc}
\hline Exposure Period & $\begin{array}{c}\mathrm{LC}_{50} \\
\left(\mathrm{mg} \mathrm{L}^{-1}\right)\end{array}$ & $\begin{array}{c}\text { Standard } \\
\text { Deviation }\end{array}$ & 95\% Confidence Limits & Slope \\
\hline $24 \mathrm{~h}$ & 10.83 & 0.51 & $(9.85-11.93)$ & 1.41 \\
$48 \mathrm{~h}$ & 8.61 & 0.38 & $(7.87-9.41)$ & 1.35 \\
$72 \mathrm{~h}$ & 7.26 & 0.32 & $(6.61-7.92)$ & 1.32 \\
$96 \mathrm{~h}$ & 6.43 & 0.24 & $(5.95-6.92)$ & 1.21 \\
\hline
\end{tabular}




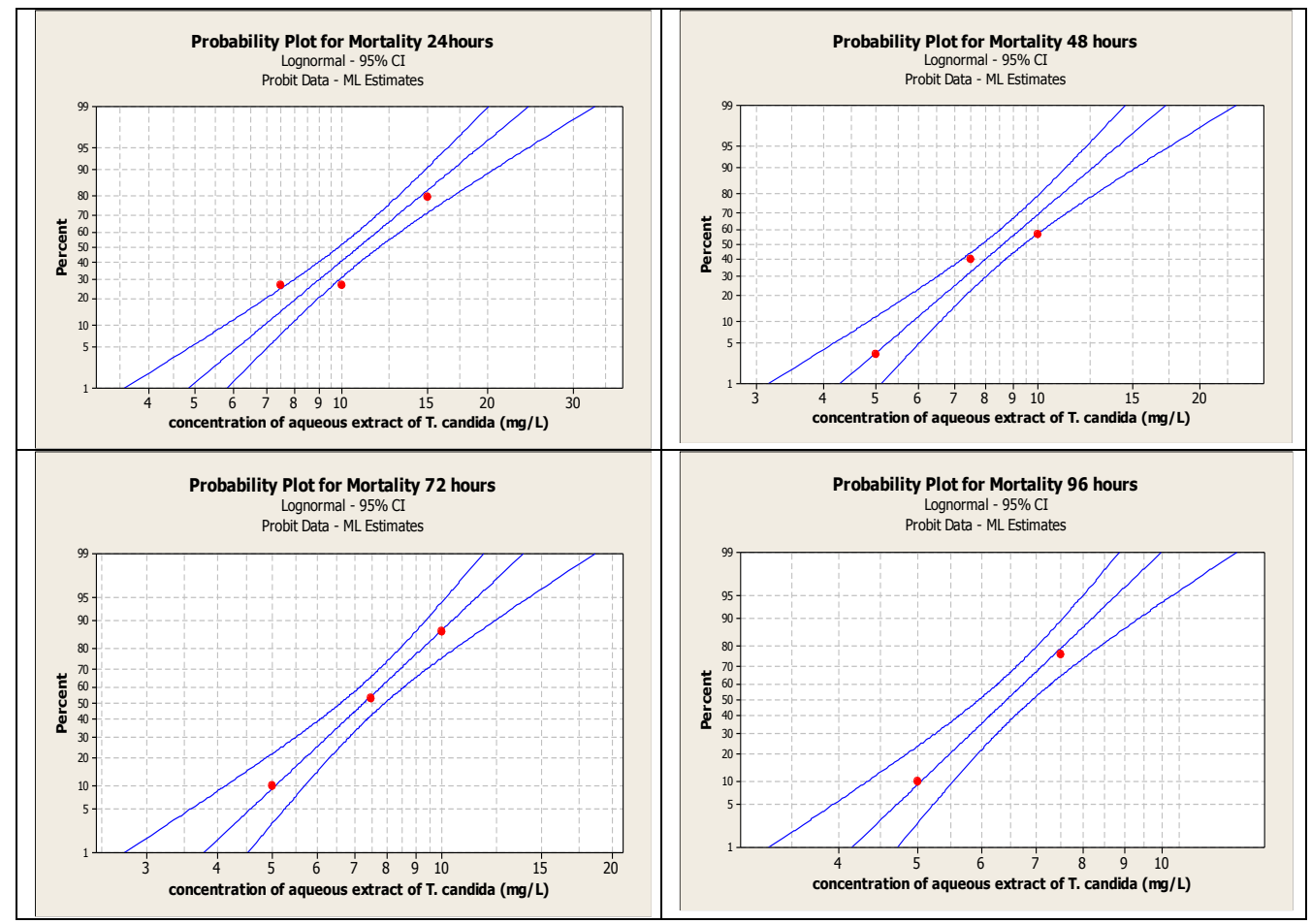

Figure 1. Mortality concentration curves obtained from probit analysis for $24 \mathrm{~h}, 48$ hour, $72 \mathrm{~h}$ and $96 \mathrm{~h}$ exposure of $O$. niloticus $(\mathrm{n}=30)$ to different concentrations of aqueous extract of $T$. candida.

\section{Discussion}

It was observed that different concentrations of $T$. candida had an inversely proportional relationship with time of exposure of $O$. niloticus as highest concentrations had the shortest duration of action and the lowest concentration when fish survived, the highest period of exposure. The 24, 48, 72 and $96 \mathrm{~h} \mathrm{LC}_{50}$ values of aqueous extract of $T$. candida on $O$. niloticus fingerlings at the $95 \%$ confidence level were $10.8,8.6,7.2$ and $6.4 \mathrm{mg} \mathrm{L}^{-1}$ respectively. The $24 \mathrm{~h} \mathrm{LC}_{50}$ value of Derris elliptica was $186 \mathrm{mg} \mathrm{L}^{-1}$ (Akinbulumo et al. 2004) and $96 \mathrm{~h} \mathrm{LC}_{50}$ to Derris root powder was $10-20 \mathrm{mg} \mathrm{L}^{-1}$ for $O$. niloticus fingerlings (Guerrero and Guerrero 1986). According to the results of the present study aqueous extract of $T$. candida showed comparatively higher toxicity on $O$. niloticus fingerlings even with very low concentrations.

Similar toxicity symptoms, shown by fingerlings of $O$. niloticus after the exposure to aqueous extract of $T$. candida, have also been shown by fingerlings of Claris gariepinus exposed to aqueous extracts of Blighia sapida and Kigelia africana (Onusiriuka and Ufodika 1994). The stressful behaviour exhibited by fish fingerlings in the present study may be the result of respiratory impairment due to the effect of the components of the extracts such as rotenone and tephrosine on the gills and general metabolism of the exposed 
fishes (Oberg 1967; Reed et al. 1967). Rotenone stuns fish by impairing their oxygen consumption (Lindahl and Öberg 1961) and its acute toxicity to fish is attributable to inhibition of nicotinamide adenine dinucleotide hydrate (NADH): ubiquinone oxidoreductase activity as the primary target (Robert et al. 1994). The specialized structure of the gills favours entrance of rotenone and other toxic compounds into the blood stream, where upon the toxicants are transported to vital organs for inhibition of respiration (Oberg 1967).

The exposed fish were motionless before death, possibly due to the loss of muscular contraction as a result of the interference of the poison with the normal functioning of the nervous system and consequently the coordination of muscular activities (Gbem et al. 1990). The damaged, swollen and bleeding gills of fish fingerlings may have caused due to the gill lesions caused by the higher concentrations of plant toxins (Onusiriuka and Ufodika 1994). O. niloticus fingerlings exposed to lower concentrations of plant extract showed loss of balance, air gulping, increased opercular movement and settling at the bottom. Similar sub lethal effects were observed on $O$. niloticus exposed to Derris powder extracts (Akinbulumo et al. 2004) and on Cyprinus carpio exposed to a concentration of pure rotenone $\left(0.1 \mathrm{mg} \mathrm{L}^{-1}\right)$ (Fajta and Grizzlea 1998).

It could be concluded that the application of $T$. candida aqueous extract causes lethal and sub lethal effects on fish even at very low concentrations hence, indiscriminate use of the T. candida as a toxicant to catch fish should be discouraged and regulated in order to protect fish biodiversity in the Sinharaja forest area. Moreover, exotic cichlid species (O. mossambicus and $O$. niloticus) support productive fisheries in inland reservoirs of Sri Lanka (Amarasinghe et al. 1989; Amarasinghe 2002) and as such, stern action should be in place to prevent spread of this harmful fishing practice to inland reservoirs. Further research is warranted to study the potential use of $T$. candida to remove invasive fish species from natural environment and to remove unwanted fish from aquaculture facilities.

\section{References}

Akinbulumo M.O., O.A. Fagbenro \& E.A. Fasakin 2004. Acute toxicity of ethanolic extract Derris elliptica root to Oreochromis niloticus fingerlings. pp 223-228. In: Bolivar R.B., G.C. Mair \& K. Fitzsimmons (eds) Proceedings of the $6^{\text {th }}$ International Symposium on Tilapia in Aquaculture. Philippine International Convention Centre, Manila, September 12-16, 2004. The Bureau of Fisheries and Aquatic Resources, Diliman, Quezon City and the American Tilapia Association, Marinsville.

Amarasinghe U.S. 2002. The Fishery and population dynamics of Oreochromis mossambicus and Oreochromis niloticus (Osteichthyes, Cichlidae) in a shallow irrigation reservoir in Sri Lanka. Asian Fisheries Science 15(1): 7-20.

Amarasinghe U.S., S.S. De Silva \& J. Moreau 1989. Spatial changes in growth and mortality and effects on the fishery of Oreochromis mossambicus (Pisces, Cichlidae) in a manmade lake in Sri Lanka. Asian Fisheries Science 3: 57-68.

Andrei C.C., P.C. Vieira, J.B. Fernande, M. Fatimadas, G.F. da Silva \& E. Rodrigues 2002. New spirorotenoids from Tephrosia candida. Verlag der Zeitschrift für Naturforschung 57: 418-422. doi: 10.1515/znc-2002-5-602

Agresti A. 1990. Categorical Data Analysis. John Wiley \& Sons, New York. 710 p. 
Cheenpracha S., C. Karalai, C. Ponglimanont \& K. Chantrapromma 2007. Cytotoxic rotenoloids from the stems of Derris trifoliata. Canadian Journal of Chemistry 85: 1019-1022. doi: 10.1139/v07-120

Dutt S.K. \& S.S. Chibber 1983. Candidol, a flavonol from Tephrosia candida. Phytochemistry 22: 325-326. doi: 10.1016/S0031-9422(00)80128-4

EIFAC 1983. Revised report on fish toxicity testing procedure. European Inland Fisheries Advisory Commission (EIFAC) Technical Paper 24, Rev.1: FAO, Rome. pp. 37.

Fajta J.R. \& J.M. Grizzlea 1998. Blood respiratory changes in common carp exposed to a lethal concentration of rotenone. Transactions of the American Fisheries Society 127(3): 512-516. doi: 10.1577/1548-8659(1998)127<0512:BRCICC>2.0.CO;2

Gbem T.T., F.A. Balogun, F.A. Lawal \& P.A. Ann 1990. Some aspects of the acute toxicity of tannery effluent to juvenile Clarias gariepinus (Teugels). Journal of Tropical Bio-Science 20 (1): 53-57.

Guerrero R.D. \& L.A. Guerrero 1989. Uses of Derris root powder for management of fresh water ponds. pp. 121-124. In: E.A. Huisman, N. Zonnerveld \& A.H.M. Bouwmans (eds) Aquaculture Research in Asia, Wageningen.

Kole R.K., C. Satpathi, A. Chowdhury, M.R. Ghosh \& N. Adityachaudhury 1992. Isolation of amorpholone, a potent rotenoid insecticide from Tephrosia candida. Journal of Agricultural and Food Chemistry 40: 1208-1210. doi: 10.1021/jf00019a026

Lindahl P.E. \& K.E. Öberg 1961. The effect of rotenone on respiration and its point of attack. Experimental Cell Research. 23(2): 228-237. doi: 10.1016/00144827(61)90033-7

Murty A.S. 1986. Toxicity of Pesticides to Fish. Volume II. CRC Press, Boca Raton, Florida $143 \mathrm{pp}$.

Negi K.S. \& K.S. Kanwal 2009. Plants used as fish toxins in Garhwal region of Uttarakhand Himalaya. Indian Journal of Traditional Knowledge. 8 (4): 535-538.

Neuwinger H.D. 1994. Fish poisoning plants in Africa. Botanica Acta 107: 263-270. doi: 10.1111/j.1438-8677.1994.tb00795.x

Oberg K.E. 1967. The reversibility of the respiratory inhibition in gills and the ultrastructural changes in chloride cells from the rotenone-poisoned marine teleost, Gadus callarias. Experimental Cell Research 45: 590-602. doi: 10.1016/00144827(67)90162-0

Onusiriuka B.C. \& F.B. Ufodike 1994. Acute toxicity of water extracts of Akee apple, Bligha sapidaand Sausage plant, Kigella africana on African catfish, Clarias gariepinus. Journal of Aquatic Sciences 9: 35-41.

Orwa C., A. Mutua, R. Kindt, R. Jamnadass \& A. Simons 2009. Agroforestry Database: a tree reference and selection guide version 4.0. Available at www.worldagroforestry.org, Retrieved on 12 September 2014.

Reed W., J. Burchard, A.J. Hopson, J. Jenness \& L. Yaro 1967. Fish and fisheries of Northern Nigeria. Ministry of Agriculture Press, Northern Nigeria.

Robert M. H., Kabeer I. A., Gadelhak G. \& McLaughlin J. L. 1994. New inhibitors of Complex I of the mitochondrial electron transport chain with activity as pesticides. Biochemical Society Transactions 22 (1) 230-233. doi: 10.1042/bst0220230

Stephen L.L., Mckenzie C.L. \& Wayne B.H. 2003. Toxicity and repellency of Tephrosia candida to larval and adult Diaprepes Root Weevil (Coleoptera: Curculionidae), 
Journal of Economic Entomology 96(3): 811-816. doi: http://dx.doi.org/10.1093/jee/96.3.811

Van Andel T. 2000. The diverse uses of fish poison plants in Northwest Guyana. Journal of Economic Botany 54(4): 500-512. doi: 10.1007/BF02866548

Wijewardene R. 1984. Techniques and tools for weed management. Proceedings of the 26th Annual Scientific Sessions, Sri Lanka Association for the Advancement of Science, Colombo. 26-30 pp. 